\title{
The effect of the coronavirus disease 2019 lockdown on type A acute aortic dissection: Insights from Bologna
}

Giacomo Murana, MD, PhD, Gianluca Folesani, MD, Luca Botta, MD, PhD, Luca Di Marco, MD, PhD, Alessandro Leone, MD, Antonino Loforte, MD, PhD, and Davide Pacini, MD, PhD, Bologna, Italy

From the Cardiac Surgery Department, S Orsola Hospital, University of Bologna, Bologna, Italy. Disclosures: The authors reported no conflicts of interest.

The Journal policy requires editors and reviewers to disclose conflicts of interest and to decline handling or reviewing manuscripts for which they may have a conflict of interest. The editors and reviewers of this article have no conflicts of interest.

Received for publication Sept 9, 2020; accepted for publication Oct 6, 2020; available ahead of print Oct 14, 2020. Address for reprints: Davide Pacini, MD, PhD, Cardiac Surgery Department, S Orsola Hospital, University of Bologna, Via Massarenti 9, 40138, Bologna, Italy (E-mail: davide.pacini@unibo.it).

JTCVS Techniques 2020;4:50-4

2666-2507

Copyright (C) 2020 The Authors. Published by Elsevier Inc. on behalf of The American Association for Thoracic Surgery. This is an open access article under the CC BY-NC-ND license (http://creativecommons.org/licenses/bync-nd/4.0/).

https://doi.org/10.1016/j.xjtc.2020.10.002

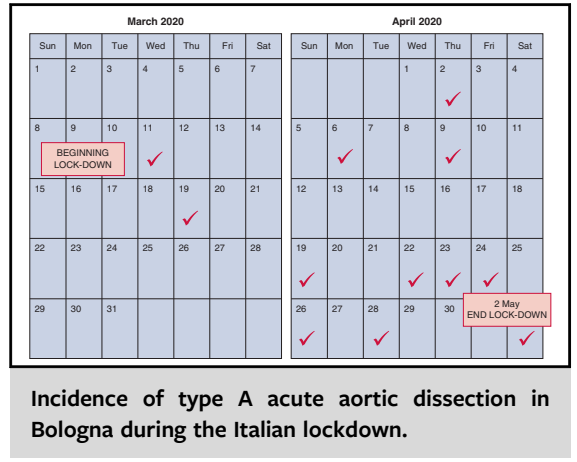

CENTRAL MESSAGE

The current COVID-19 pandemic could indirectly influence in the frequency and manifestation of type $A$ acute aortic dissection.

See Commentary on page 55. surge in the number of cases, the Italian government imposed, from March 9 to May 4, 2020, specific mobility restrictions (ie, lockdown).

At the same time, the progressively increasing number of patients with pneumonia who needed intensive care unit treatment led to a reorganization of the entire health care system, with a significant reduction in cardiac surgery and research activities. ${ }^{2}$ In the epicenter of the Italian epidemic, 16 of 20 cardiac surgery units completely discontinued their activities, resulting in the remaining 4 centers being considered the hub hospitals where emergency and urgent operations have been performed. ${ }^{3}$ However, Italy is a long peninsula and it was not uniformly affected by the pandemic. Bologna, located in Emilia Romagna (the third region of Italy for number of infections) was among the main regional hub centers attending the COVID-19 network.

The aim of this brief report was to investigate the influence of COVID-19 during the spring 2020 peak of the pandemic on the incidence and manifestation of type $A$ acute aortic dissection (type A-AAD) in Italy.

Bologna University's Institutional Review Board determined that this study is exempt from institutional review board submission although all patients (and/or relatives) gave us consent to use personal information. It was also conducted in accordance with the ethical principles established in the Declaration of Helsinki.

\section{SPECIFIC ASPECTS AND REFLECTIONS REGARDING TYPE A-AAD}

Our department at S Orsola Hospital represents the hub center for cardiac interventions in the metropolitan area of Bologna and the only referral hospital for all acute aortic syndromes.

Surgical activity was confined to emergency/urgent cases and to operations that could not be postponed beyond a month. Our intensive care unit and ward were $75 \%$ dedicated to COVID-19 patients, and during the first quarter of this year we performed 222 cardiovascular surgical procedures, a $30 \%$ reduction compared with the same period of 2019.

However, during the lockdown restrictions an unusual trend in the incidence of type A-AAD was observed (Figure 1). During the springtime peak of the pandemic in March 2020, we had a severe reduction in the diagnosis of type A-AAD (only 2 patients were treated). On the contrary, during April 2020 we faced a progressive increase of type A-AAD $(n=10)$ with a peak of incidence at the end of the national lockdown (Figure 2). Clinical and radiological signs of organ malperfusion were frequently observed (6 out of 10 patients). Moreover, we detected an increase in the 


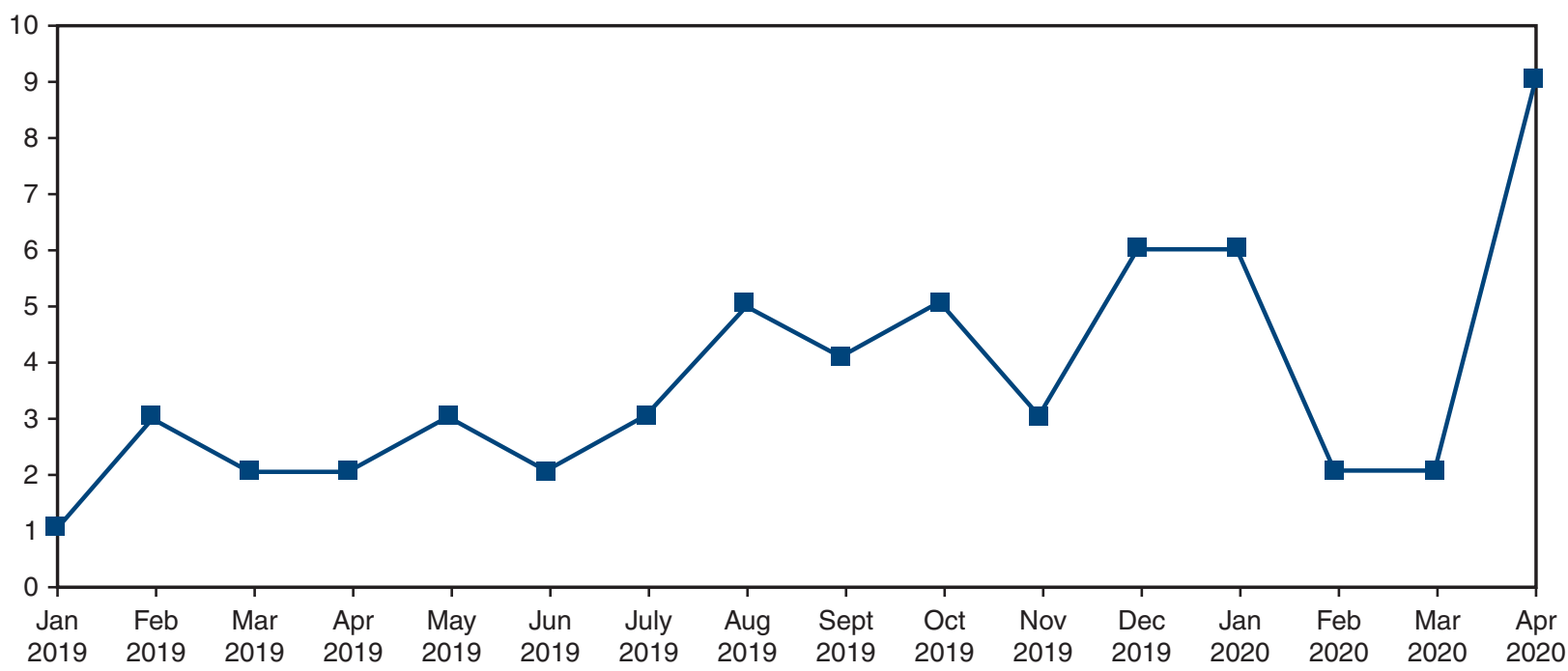

FIGURE 1. Graph showing the trend of patients with type A acute aortic dissection admitted to our department from January 2019 to the end of the spring 2020 coronavirus disease 2019 lockdown.

time between the onset of symptoms and the hospital admission (mean, 10.3 hours). Three patients died before arriving in the operating room. A fourth patient died 2 days after the implantation of an uncovered stent-graft in the abdominal aorta before surgical repair due to severe mesenteric malperfusion and extremely poor clinical conditions.
The unusually high incidence of complicated type A-AAD was probably related to a treatment delay and to the consequent progression of the aortic disease. To understand this phenomenon, all surviving patients, relatives, and medical personnel involved during this period were interviewed (Table 1).
March 2020

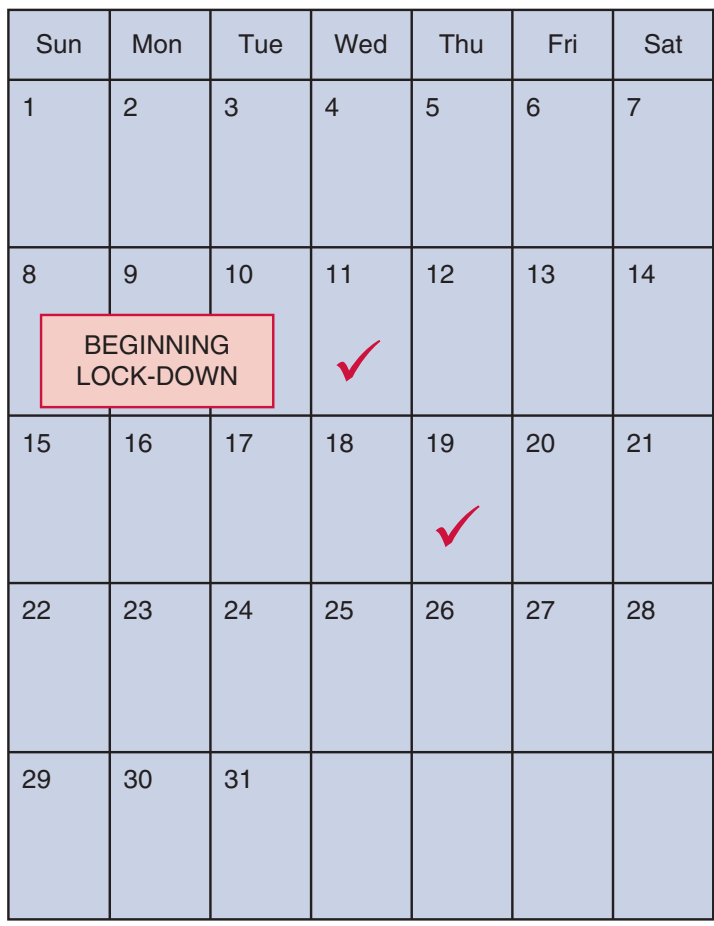

April 2020

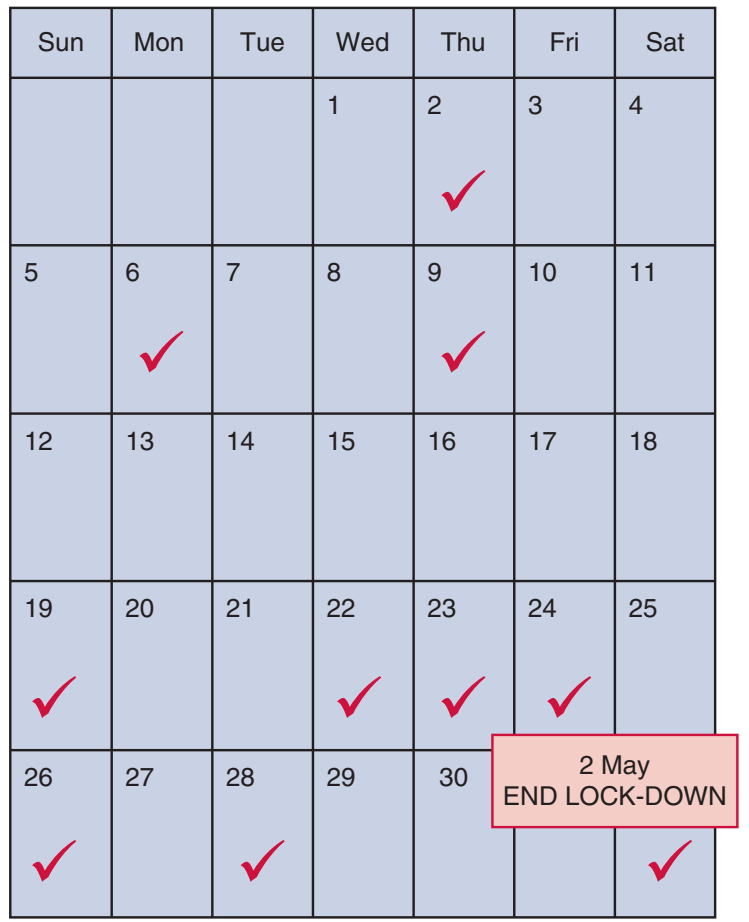

FIGURE 2. Incidence of type A acute aortic dissection in Bologna during the Italian lockdown. 
U TABLE 1. Description of patients admitted to the local emergency department (ED) in Bologna with diagnosis of type A acute aortic dissection during the spring 2020 Italian lockdown (N=10)

\begin{tabular}{|c|c|c|c|c|c|c|c|c|c|c|c|c|}
\hline \multirow[b]{2}{*}{ Patient } & \multicolumn{4}{|c|}{ Time (min) } & \multirow{2}{*}{\multicolumn{2}{|c|}{$\begin{array}{c}\text { Radiologic } \\
\text { signs of } \\
\text { Characteristics ground-glass }\end{array}$}} & \multirow[b]{2}{*}{$\begin{array}{r}\text { Preoperative } \\
\text { malperfusion }\end{array}$} & \multirow[b]{2}{*}{$\begin{array}{c}\text { Death } \\
\text { before } \\
\text { operation }\end{array}$} & \multirow[b]{2}{*}{$\begin{array}{l}\text { Operation } \\
\text { performed }\end{array}$} & \multirow[b]{2}{*}{$\begin{array}{c}\text { Postoperative } \\
\text { stroke }\end{array}$} & \multirow[b]{2}{*}{$\begin{array}{l}\text { Hospital } \\
\text { mortality }\end{array}$} & \multirow[b]{2}{*}{$\begin{array}{l}\text { Hospital } \\
\text { stay (d) }\end{array}$} \\
\hline & 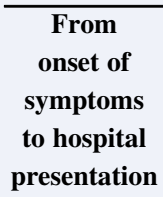 & $\begin{array}{c}\text { From } \\
\text { triage to } \\
\text { diagnosis }\end{array}$ & $\begin{array}{c}\text { From } \\
\text { ED to hub } \\
\text { center for } \\
\text { cardiac } \\
\text { surgery }\end{array}$ & $\begin{array}{l}\text { From } \\
\text { ED to skin } \\
\text { incision }\end{array}$ & & & & & & & & \\
\hline $\begin{array}{l}79 \text { aa, } \\
\text { female }\end{array}$ & 220 & 130 & $188(+58)$ & $320(+132)$ & $\begin{array}{l}\text { Intimal tear in } \\
\text { the ascending } \\
\text { aorta, IMH in } \\
\text { the } \\
\text { descending } \\
\text { and } \\
\text { abdominal } \\
\text { portions }\end{array}$ & Yes & Mesenteric & No & AVR + Hemiarch & No & No & 15 \\
\hline $\begin{array}{l}41 \text { aa, } \\
\text { male }\end{array}$ & 240 & 150 & $240(+90)$ & $350(+110)$ & $\begin{array}{l}\text { Complete } \\
\text { obstruction of } \\
\text { the TL in the } \\
\text { abdominal } \\
\text { portion }\end{array}$ & No & Mesenteric & No & Bentall + FET & No & No & 31 \\
\hline $\begin{array}{l}66 \text { aa, } \\
\text { male }\end{array}$ & 2880 & 1620 & $1771(+151)$ & $1866(+95)$ & $\begin{array}{l}\text { Aortic } \\
\text { dissection } \\
\text { limited to the } \\
\text { ascending } \\
\text { aorta and arch }\end{array}$ & No & No & No & Hemiarch & No & No & 12 \\
\hline $\begin{array}{l}51 \text { aa, } \\
\text { male }\end{array}$ & 80 & 120 & $140(+20)$ & $270(+130)$ & $\begin{array}{l}\text { Ipoperfusion of } \\
\text { the inferior } \\
\text { mesenteric } \\
\text { artery }\end{array}$ & No & No & No & Complete arch & No & No & 12 \\
\hline $\begin{array}{l}85 \text { aa, } \\
\text { male }\end{array}$ & 300 & 180 & $259(+79)$ & $439(+180)$ & $\begin{array}{l}\text { Type A IMH } \\
\text { with } \\
\text { extravasation } \\
\text { of contrast in } \\
\text { the ascending } \\
\text { portion }\end{array}$ & No & No & No & AVR + Hemiarch & No & No & 12 \\
\hline $\begin{array}{l}73 \text { aa, } \\
\text { male }\end{array}$ & NA & 60 & $214(+154)$ & $330(+116)$ & $\begin{array}{l}\text { Complete } \\
\text { obstruction of } \\
\text { TL in the } \\
\text { descending } \\
\text { thoracic and } \\
\text { abdominal } \\
\text { portions }\end{array}$ & No & Mesenteric & $\begin{array}{c}\text { Yes, patients } \\
\text { underwent } \\
\text { emergent } \\
\text { TEVAR to } \\
\text { treat mesenteric } \\
\text { ischemia }\end{array}$ & TEVAR & - & Yes & 3 \\
\hline
\end{tabular}




\begin{tabular}{|c|c|c|c|c|c|c|c|c|c|c|c|c|}
\hline \multirow[b]{2}{*}{ Patient } & \multicolumn{4}{|c|}{ Time (min) } & \multirow{2}{*}{\multicolumn{2}{|c|}{$\begin{array}{c}\text { Radiologic } \\
\text { signs of } \\
\text { Characteristics ground-glass }\end{array}$}} & \multirow[b]{2}{*}{$\begin{array}{l}\text { Preoperative } \\
\text { malperfusion }\end{array}$} & \multirow[b]{2}{*}{$\begin{array}{c}\text { Death } \\
\text { before } \\
\text { operation }\end{array}$} & \multirow[b]{2}{*}{$\begin{array}{l}\text { Operation } \\
\text { performed }\end{array}$} & \multirow[b]{2}{*}{$\begin{array}{c}\text { Postoperative } \\
\text { stroke }\end{array}$} & \multirow[b]{2}{*}{$\begin{array}{r}\text { e Hospital } \\
\text { mortality }\end{array}$} & \multirow[b]{2}{*}{$\begin{array}{c}\text { Hospital } \\
\text { stay (d) }\end{array}$} \\
\hline & $\begin{array}{c}\text { From } \\
\text { onset of } \\
\text { symptoms } \\
\text { to hospital } \\
\text { presentation }\end{array}$ & $\begin{array}{c}\text { From } \\
\text { triage to } \\
\text { diagnosis }\end{array}$ & $\begin{array}{c}\text { From } \\
\text { ED to hub } \\
\text { center for } \\
\text { cardiac } \\
\text { surgery }\end{array}$ & $\begin{array}{l}\text { From } \\
\text { ED to skin } \\
\text { incision }\end{array}$ & & & & & & & & \\
\hline $\begin{array}{l}68 \text { aa, } \\
\text { male }\end{array}$ & 540 & 47 & $120(+73)$ & - & $\begin{array}{l}\text { Severe } \\
\text { Tamponade, } \\
\text { involvement } \\
\text { of both } \\
\text { coronary } \\
\text { arteries }\end{array}$ & No & $\begin{array}{c}\text { Coronary and } \\
\text { cerebral }\end{array}$ & Yes & - & - & Yes & 0 \\
\hline $\begin{array}{c}79 \text { aa, } \\
\text { male }\end{array}$ & 60 & 30 & $90(+60)$ & - & $\begin{array}{l}\text { Mediastinal } \\
\text { hematoma } \\
\text { and acute } \\
\text { TED }\end{array}$ & Yes & Cerebral & $\begin{array}{l}\text { Yes, patients } \\
\text { died in the } \\
\text { intensive care } \\
\text { unit while } \\
\text { preparing for } \\
\text { the operating } \\
\text { room }\end{array}$ & - & - & Yes & 0 \\
\hline $\begin{array}{l}63 \text { aa, } \\
\text { male }\end{array}$ & NA & $10 *$ & - & - & $\begin{array}{l}\text { Severe } \\
\text { involvement } \\
\text { of epiaortic } \\
\text { vessels }\end{array}$ & No & Cerebral & Yes & - & - & Yes & 0 \\
\hline $\begin{array}{l}81 \text { aa, } \\
\text { female }\end{array}$ & NA & 140 & $220(+140)$ & $\begin{array}{l}\text { Postponed } \\
\text { for clinical } \\
\text { reason }\end{array}$ & $\begin{array}{l}\text { Severe } \\
\text { dilatation of } \\
\text { the ascending } \\
\text { aorta }(7.2 \mathrm{~cm})\end{array}$ & Yes & No & No & AVR + Hemiarch & No & No & 20 \\
\hline Summary & $617(60-2880)$ & $48.7(10-16$ & $360.2(90-177$ & $95.8(270-1866)$ & - & $3 / 10$ & $6 / 10$ & $4 / 10$ & - & $0 / 10$ & $4 / 10$ & $10.5(0-31)$ \\
\hline
\end{tabular}

Values are presented as median (range). $C T$, Computed tomography; $E D$, emergency department; $a a$, age; $I M H$, intramural hematoma; $A V R$, aortic valve replacement; $T L$, true lumen; $F E T$, frozen elephant trunk; $T E V A R$, thoracic endovascular aortic repair; TED, acute thromboembolic disease, $N A$, not available. *Patient was found in a coma at home. 


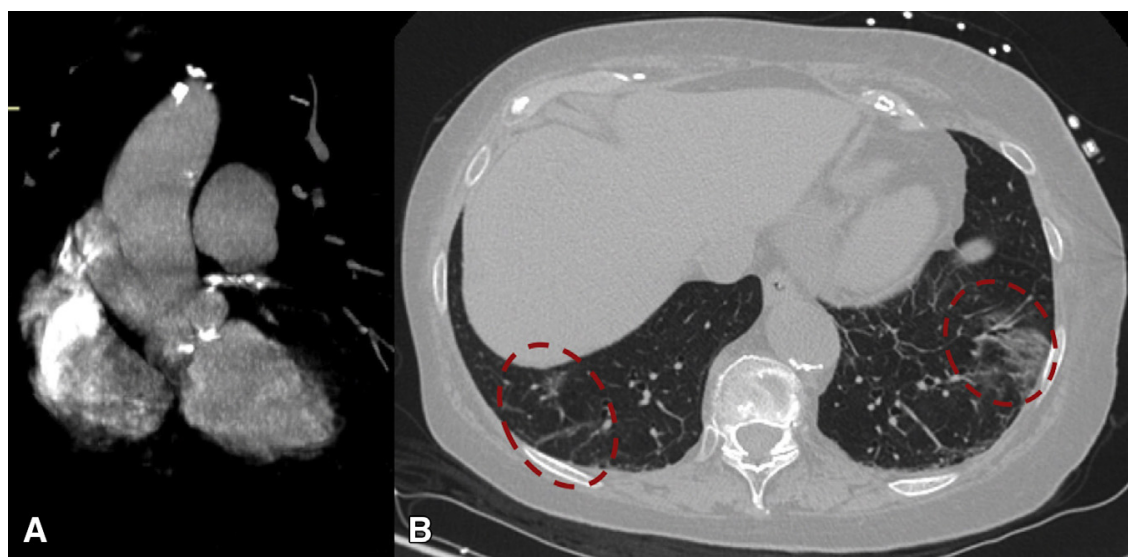

FIGURE 3. Angio-computed tomography scan of a patient with type A acute aortic dissection (A) suspected to be infected with coronavirus disease 2019 due to unspecific bilateral pulmonary infiltrates suggestive of interstitial pneumonia (B).

According to the clinical records and interviews these are our final observations:

- A delay in the diagnosis was observed. The reason was related to patients' fear of leaving their home during a period of severe imposed restrictions. The ban on personal contacts forced or inhibited patients from going to the hospital. According to what we observed in April 2020, 4 out of 10 cases were influenced by this phenomenon. This could explain the significant increase of type A-AAD admissions close to the end of the lockdown period. A second possible explanation might be correlated to the longer time required to organize diagnostic examinations and patients transfers between departments in the hospital. Mean time from triage to angio-computed tomography scan and to operating room was 1.5 and 9.9 hours, respectively.

- All patients admitted to our department were considered to be suspect for infection with COVID-19 (while waiting for the swab result). Three out of 10 cases were strongly suspected for COVID-19 infection because of radiological signs of ground-glass area suggestive for interstitial pneumonia (Figure 3). Misdiagnosis at computed tomography scan has already been described. ${ }^{4}$ According to our safety protocols, each surgeon wore specific personal protective equipment: surgical masks, visor (face shield), long gown, 2 pairs of gloves, 2 caps, and shoe covers. However, our routine management of patients with acute aortic dissections in terms of preoperative planning and operative strategy did not change during the pandemic.

- Zero patients had a positive COVID-19 test according to the nasal swab and all 6 patients who arrived alive in the operating room were successfully treated with a regular postoperative course. Despite the major difficulty in the management of emergency patients during the COVID-19 pandemic, we reported good surgical results: all 6 patients who arrived alive in the operating room were successfully treated and they did not present any significant complications during the postoperative course. However, we recognize that none of these patients were infected with COVID-19 and this may have had a favorable influence on the outcomes.

\section{CONCLUSIONS}

The outbreak of COVID-19 continues to constitute a public health emergency of international concern influencing time to diagnosis and causing a delay in the treatment of cardiac diseases. Many countries are now facing the peak of the pandemic, whereas others are aware of a new diffusion of the infection in the coming months; therefore, it is essential to promote medical care assistance for all elective and acute pathologies in this evolving scenario. This concept is even more appropriate when considering type A-AAD because time saves lives!

\section{References}

1. Civil Protection Service. COVID-19, situation in Italy. Available at: http://www. salute.gov.it/portale/nuovocoronavirus/dettaglioContenutiNuovoCoronavirus.jsp? lingua $=$ english $\& \mathrm{id}=5367 \&$ are $=$ nuovoCoronavirus $\&$ menu $=$ vuoto. $\quad$ Accessed October 20, 2020.

2. Gaudino M, Chikwe J, Hameed I, Robinson NB, Fremes SE, Ruel M. Response of cardiac surgery units to COVID-19: an internationally-based quantitative survey. Circulation. 2020;142:300-2.

3. Bonalumi G, di Mauro M, Garatti A, Barili F, Gerosa G, Parolari A, et al. The COVID-19 outbreak and its impact on hospitals in Italy: the model of cardiac surgery. Eur J Cardiothorac Surg. 2020;57:1025-8.

4. Ye Z, Zhang Y, Wang Y, Huang Z, Song B. Chest CT manifestations of new coronavirus disease 2019 (COVID-19): a pictorial review. Eur Radiol. 2020;30: 4381-9. 